\title{
Histological evaluation of vitamin-D deficiency on the endometrial decidualization in early pregnancy in rat model
}

\section{Original Article}

\author{
Samaa Samir Kamar \\ Department of Medical Histology, Faculty of Medicine, Cairo University, Cairo, Egypt
}

\begin{abstract}
Introduction: Vitamin-D is a pleiotropic secosteroid hormone that exerts classical effect in calcium uptake and bone metabolism. In addition, it has non-classical effects on variety of organs. Endometrial decidualization, placentation, and the development of the embryo itself have all pivotal roles for normal pregnancy outcomes after embryo implantation. Early maternal decidua and fetal trophoblast cells illustrate expression of vitamin-D receptor and $1 \alpha$-hydroxylase enzyme that catalyzes vitamin-D into the active metabolite, calcitriol.

Aim: To record the histological effect of vitamin-D deficiency on endometrial decidualization during early pregnancy on day 8 post-coitum.

Materials and Methods: Thirty female albino rats were divided into 2 groups: control group (GpI) and vitamin-D deficient group (GpII). After establishment of pregnancy, the animals were sacrificed on the 8th gestational day. The bicornuate pregnant uteri were processed for histological analysis using H\&E and PAS stains in addition to immunohistochemical staining for osteopontin (OSP), as a marker for decidualization, and for CD34 to assess the decidual angiogenesis. Morphometric and statistical studies were performed.

Results: Substantial decrease in the number of implantation sites in vitamin-D deficient rats was noted by gross examination. Histological examination revealed significant decrease in endometrial thickness at the antimesometrial region with remarkably impaired stromal cells differentiation. PAS staining illustrated fewer PAS positively stained uterine natural killer cells compared to control. Weak cytoplasmic OSP immunostaining was observed in the luminal as well as glandular epithelium, vascular endothelium and few stromal cells in mesometrial region. CD34 immunostaining demonstrated impaired angiogenesis in the lateral decidua as compared to control. These findings were confirmed by morphometric and statistical analysis.

Conclusion: Vitamin-D deficiency impairs the uterine stromal cells differentiation, affects the immunity tolerance and weakens decidual angiogenesis during early pregnancy in rat model.
\end{abstract}

Received: 26 April 2018, Accepted: 5 June 2018

Key Words: CD34, decidualization, osteopontin, vitamin-D deficiency.

Corresponding Author: Samaa Samir Kamar, Department of Medical Histology, Faculty of Medicine, Cairo University, Cairo, Egypt, Tel.: +2 01008909069, E-mail: dr_samaakamar@yahoo.com.

ISSN: 1110-0559, Vol. 41, No. 3

\section{INTRODUCTION}

Endometrial decidualization, placentation, and the development of the embryo itself are all important for normal pregnancy outcomes after blastocyst implantation. Decidualization is a precise remodeling of the maternal uterine tissue to provide nourishment for the developing blastocyst before placental formation and to protect the embryo from being attacked by maternal immunity ${ }^{[1]}$. The endometrial decidualization includes terminal differentiation of stromal cells into decidual cells, uterine angiogenesis and abundant recruitment of immune cells especially uterine natural killer cells (uNK) and macrophages $^{[2]}$.

Rats have been effectively used as an appropriate model for studying the remodeling of uterine tissue during pregnancy and the physiological mechanisms controlling it, in contrast to human ${ }^{[3]}$. In rats, implantation occurs between days 4 and 5 of pregnancy, during which the uterus is receptive to blastocysts and known as window of implantation ${ }^{[4]}$. Decidual reaction in rat occurs in response to blastocyst implantation or artificial stimuli ${ }^{[5]}$.

Decidualization of the stromal cells in the rat occurs in two stages. It first starts in the antimesometrial region on day 6 of pregnancy and reach its maximum development on day 10 then enters a period of regression until they are entirely absent by day 16 . The second stage develops in the mesometrial region from 8th to 12th day post-coitum, and includes transforming the uterine stromal cells into the decidual cells ${ }^{[4]}$. Decidual angiogenesis is considered the initial fetal-maternal exchange apparatus. Thus, it is a crucial process for embryonic survival and maintenance of pregnancy ${ }^{[6]}$. Decidualization of each region is dependent on expression of hormone receptors, local factors and 
growth cytokines mediated by progesterone ${ }^{[7]}$.

Vitamin-D is a major regulator of calcium and phosphate homeostasis. Calcitriol is the most potent metabolite of vitamin-D. It is also known as 1,25-dihydroxyvitamin $\mathrm{D} 3\left(1,25(\mathrm{OH})_{2} \mathrm{D}_{3}\right)$, which has been documented to possess variety of functions not immediately related to ion homeostasis ${ }^{[8]}$. Calcitriol has a key role in immune tolerance by regulating $\mathrm{T}$-cell maturation into effector and regulatory $\mathrm{T}$ cells ${ }^{[9]}$. Progesterone substantially enhances the T-cell response to calcitriol. Thus, there is a clear synergistic corporation between vitamin $\mathrm{D}$ and calcitriol in regulating $\mathrm{T}$ cells and tolerating decidual immunity in pregnancy ${ }^{[10]}$. Noteworthy, early pregnant maternal decidua and fetal trophoblast cells can express both vitamin D receptor and $1 \alpha$-hydroxylase enzyme that converts $25(\mathrm{OH}) \mathrm{D}_{3}$ into $1,25(\mathrm{OH})_{2} \mathrm{D}_{3}^{[11]}$.

\section{MATERIALS AND METHODS}

\section{Animals:}

Thirty adult female Sprague Dawley albino rats, 4-weeks old bred in the Animal House of Ophthalmology Research Center were included in the study. All procedures were held under ethical guidelines for the use and care of animals. The animal protocol was approved by the Institutional Animal Care and Use Committee of Cairo University. Rats were divided into 2 equal number groups 15 , each as followed:

- Control group (GpI) rats fed ad libitum a standard routine chow diet for 6 weeks before mating and throughout the 7 days of gestation. They were maintained in daylight controlled room with light/dark cycle 12:12 h. Normal serum blood level of vitamin-D (Vit-D) was assured before matting.

- Vitamin D deficient rats (GpII) were kept for 6 weeks before mating and throughout the 7 days of gestation on a Vit-D deficient diet (containing 20\% lactose, 2\% Calcium and $1.25 \%$ Phosphate). In addition, animals were housed under incandescent lighting to avoid Vit-D activation by ultraviolet rays. The model was verified by serum blood low level of vitamin-D (below $15 \mathrm{nmol} / \mathrm{L}$ ) in all included animals before matting ${ }^{[12]}$.

\section{Establishment of pregnancy}

The sexual maturity of the experimental rats was attained by monitoring their estrous cycle using vaginal smear. Nulliparous 10 -weeks estrous female rats were bred overnight with fertile males of the same strain (female to male ratio $=1: 1$ ) to allow matting. Morning examination was done every day for detection of the vaginal semen plug and sperms intermingled with the cornified cells in the vaginal smear that indicates day 1 pregnancy ${ }^{[13]}$.
Continuous di-oestrus vaginal smears confirmed the pregnancy ${ }^{[5]}$. Thirteen out of the fifteen rats get pregnant in GpI, while ten out of fifteen rats get pregnant in GpII. The dams underwent only follow up until the 8th day of pregnancy. Ten pregnant rats from each group were sacrificed and subjected to histological assessment.

\section{Histological Analysis}

All animals were anesthetized using intraperitoneal injection of thiopental sodium $(50 \mathrm{mg} / \mathrm{kg})^{[14]}$ and sacrificed at the 8th day of gestation. The uterus was exposed through laparotomy and the right and left pregnant horns were isolated, cleaned from attached fatty tissue. The pregnant uteri possessed scattering nodes (implantation sites), indicating decidualization. The uteri were transversely cut at the widest area of these nodes and placed in Bouin's solution overnight. Paraffin blocks were processed and 5-7 $\mu \mathrm{m}$ thick sections were subjected to:

1- Hematoxylin and eosin (H\&E) staining to determine structural changes ${ }^{[15]}$ and PAS staining to visualize the uterine natural killer cells $(\mathrm{uNK})^{[1]}$.

2- Immunohistochemical staining using anti-osteopontin polyclonal antibody (Ab) (Thermo Scientific, RB9097-R7) as a marker of decidualization ${ }^{[16]}$, and anticluster differentiation 34 (CD34) monoclonal Ab (Thermo Scientific, MA1-10202) as a marker for endothelial progenitor cells and endothelial cells of blood vessels to assess the decidual angiogenesis ${ }^{[6]}$. Application of the primary $\mathrm{Ab}$ was followed by incubation in humidity chamber for about $60 \mathrm{~min}$ at room temperature. Immunostaining was proceeded by the use of Ultravision detection system. Sections were co-stained with Meyer's hematoxylin to visualize the nucleus.

\section{Morphometry and Statistical Analysis}

The following parameters were accomplished:

1- The number of implantation sites in the uterine horns/rat in both groups was assessed by gross examination.

2- The thickness of the decidualized endometrium at the antimesometrial region in $\mathrm{H} \& \mathrm{E}$ stained sections at low power field $(\mathrm{x} 40)$ using Olympus-DP27 digital camera (Japan). Ten readings were taken for each rat.

3- The number of uNK cells/ high power field (HPF) in PAS stained sections was counted in 10 non-overlapping randomly chosen fields/rat using Olympus-DP27 digital camera.

4- The area $\%$ of positive $(+v e)$ osteopontin immunestaining in 10 non-overlapping randomly chosen HPF/ rat (x400) using "Leica Qwin $500 \mathrm{C}$ " image analyzer (Cambridge, UK).

Quantitative data were summarized as means \pm standard deviations (SD) and compared using T-test. The probability value $<0.05$ was considered statistically 
significant. Calculations were made on Statistical Package of Social Science software (SPSS), Version 19 (Chicago, CA).

\section{RESULTS}

\section{Gross Examination}

The uterine horns of Vit-D deficient rats (GpII) had significant less number of implantation sites in uterine horns $(6 \pm 0.81)$ compared to control rats $(\mathrm{GpI})(11.4 \pm 0.97)$ [Figure 1], indicating impaired pregnancy in vitamin-D deficiency.

\section{Hematoxylin and Eosin Staining:}

The histological analysis of the decidualized endometrium demonstrated antimesometrium, mesometrium and lateral decidua [Figure 2]. In GpI, the antimesometrial region exhibited remarkable full differentiation of stromal cells into numerous large and small decidualized cells. In addition, the proliferative capacity of decidual cells was demonstrated by presence of many mitotic figures and dividing cells [Figure 3a and 3b]. While the mesometrial region showed smaller cells with irregular shape and a single nucleus. Large venous sinusoids containing leukocytes were noted in the lateral decidua [Figure $4 \mathrm{a}$ and $4 \mathrm{~b}$ ]. Vit-D deficiency rats (GpII) showed remarkably impaired stromal cells differentiation with significant decrease in the mean endometrial thickness $(131.6 \pm 3.5)$ at the antimesometrial region compared to control animals $(201.5 \pm 5.4)$ [Figure $3 \mathrm{c}$ and $3 \mathrm{~d}$ ]. Small irregular shaped stromal cells with single nucleus at the mesometrial region and small blood vessels with narrow lumen at the lateral decidua were observed [Figure $4 \mathrm{c}$ and $4 \mathrm{~d}$ ].

\section{PAS Staining}

Numerous uNK cells with PAS +ve reaction were detected in GpI. While Gp II exhibited significant decrease in the number of PAS positively stained uNK cells [Figure 5]. The mean number of counted cells/ HPF was $12.8 \pm 1.8$ in GpI versus $4.3 \pm 1.2$ in GpII.

\section{Immunohistochemistry Staining}

On day 8 of pregnancy, OSP immunostaining in GpI showed strong +ve cytoplasmic localization in the luminal and glandular epithelium, vascular endothelium and numerous stromal cells in the mesometrial region. In addition, numerous decidual cells in the antimesometrial region with +ve strong cytoplasmic immunostaining were detected [Figure $6 \mathrm{a}$ and $6 \mathrm{~b}$ ]. GpII demonstrated weak cytoplasmic OSP immunostaining in the luminal and glandular epithelium, vascular endothelium and few stromal cells in the mesometrial region, in addition to few decidualized cells in the antimesometrial region [Figure $6 \mathrm{c}$ and $6 \mathrm{~d}$ ]. The mean area $\%$ of OSP immunostaining in GpII was significantly decreased as compared to GpI [Figure 7].

Immunostaining of CD34 showed numerous elongated dilated vascular sinusoids, closely related to decidual cells in the in the lateral decidua (the transition zone between mesometrial and antimesometrial region) of GpI. Impaired formation of decidual angiogenesis was observed in the GpII in the lateral decidua of GPII [Figure 8].
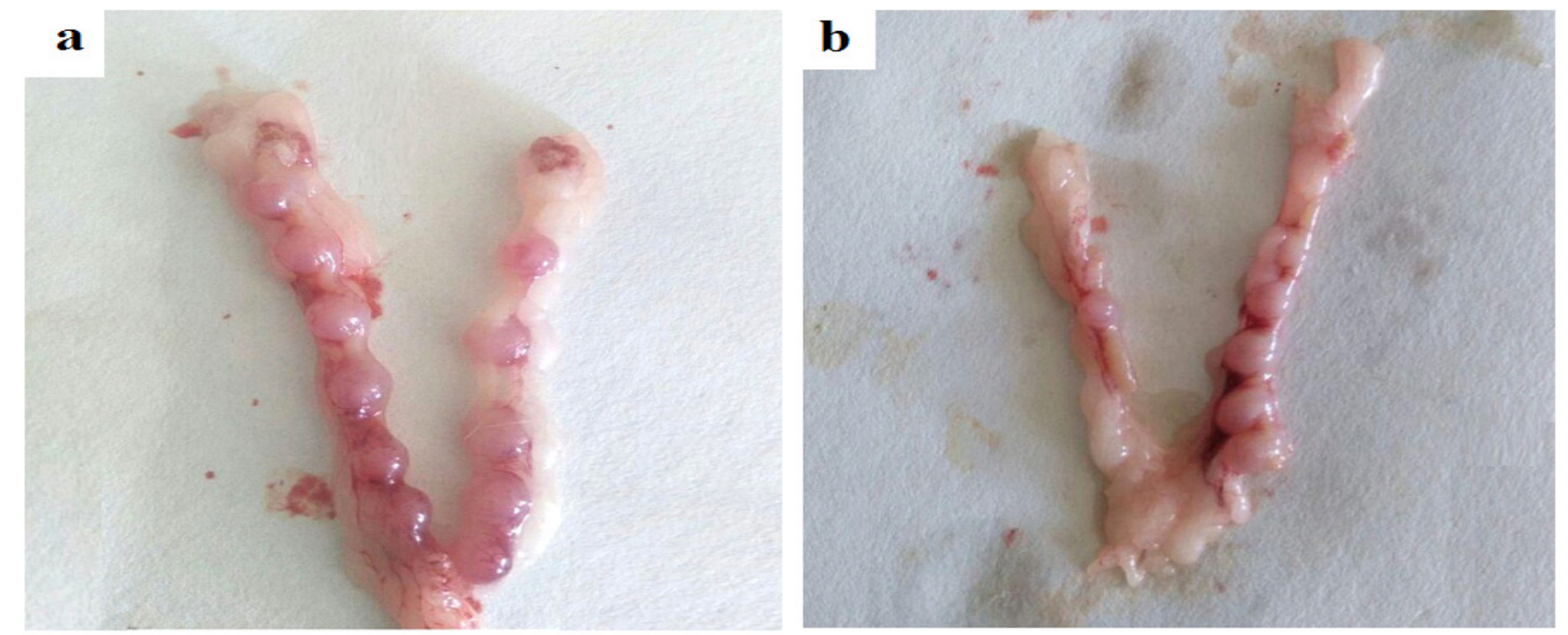

Fig. 1: Gross uterine morphology 8th day of pregnancy showing (a): The uterus of the control group showing eleven implantation sites in both horns, (b): The uterus of vit-D deficiency group illustrating one implantation site in the left horn and five implantation sites in right, in addition they appear invariably smaller. 


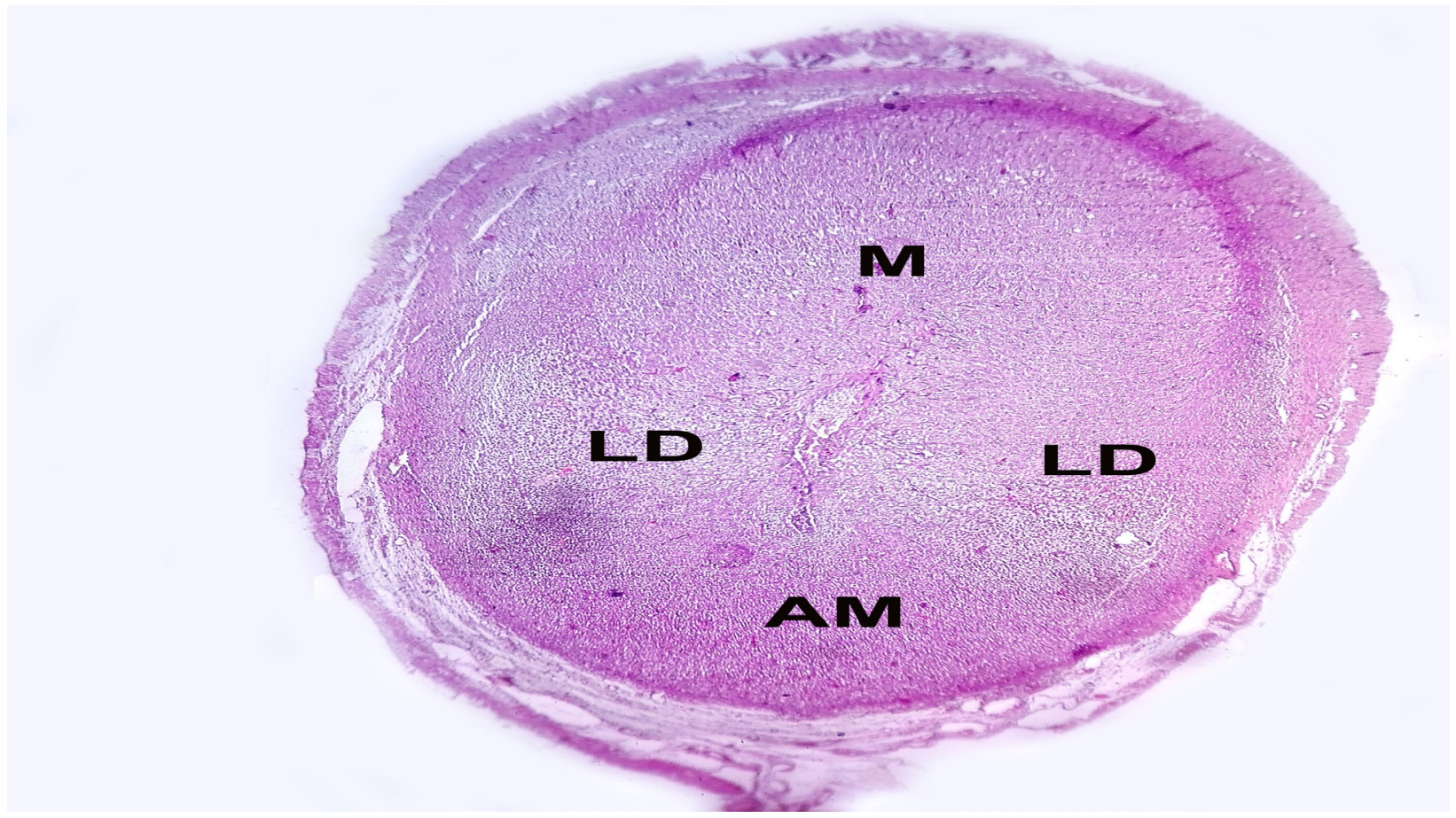

Fig. 2: Photomicrograph of H\&E stained section in the implantation chamber of control rat at 8th day of pregnancy showing different regions of the decidua (x original 40). (AM) Antimesometrial region, (M) Mesometrial region, (LD) Lateral decidua.
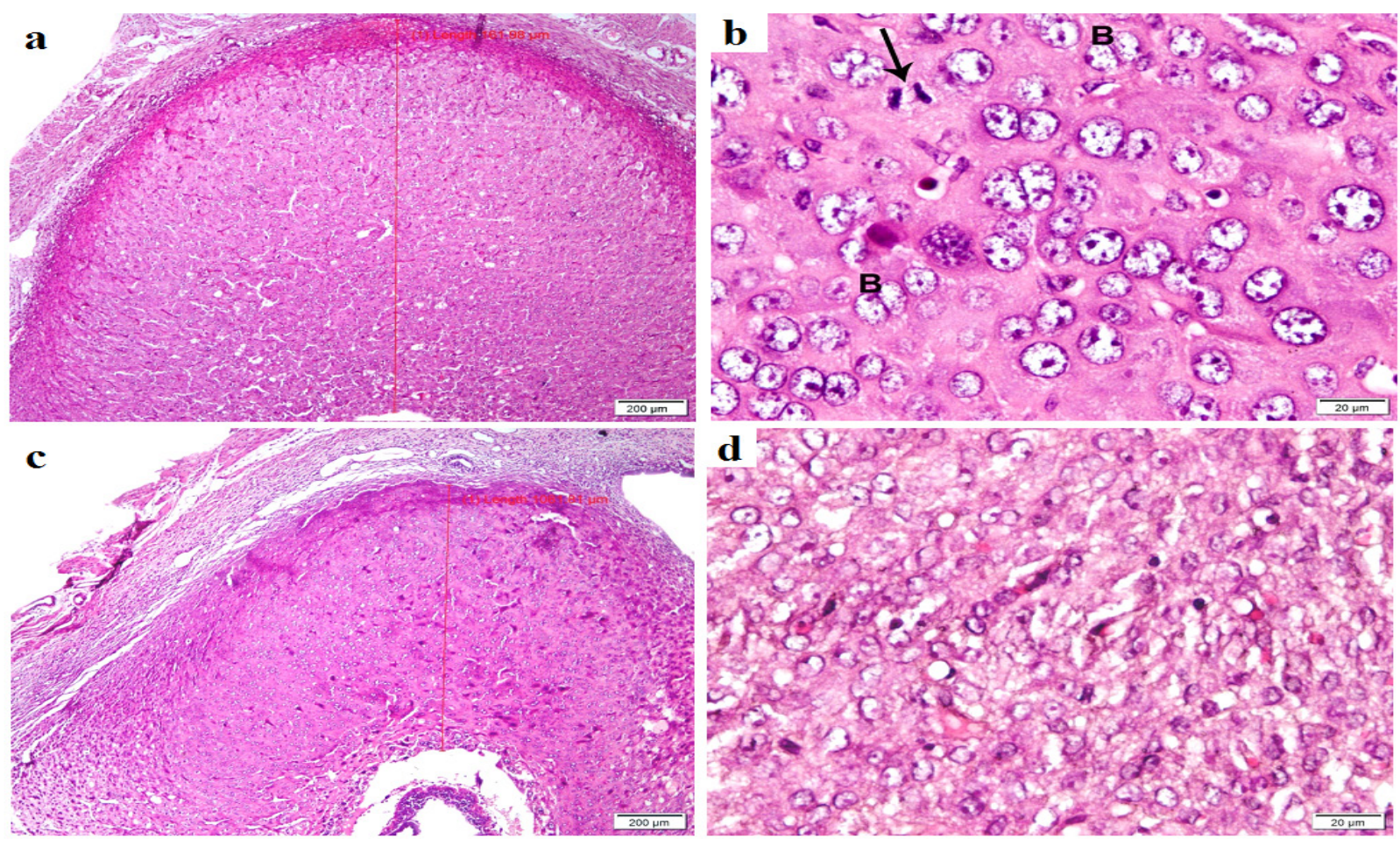

Fig. 3: Photomicrograph of H\&E stained sections showing the antimesometrial region of the rat uteri at day 8 of pregnancy. GpI illustrating (a) thick endometrial decidualization (from the lumen to the myometrium), (b) obvious decidualization of the stromal cells into numerous large and small rounded decidual cells with abundant eosinophilic cytoplasm, large round vesicular nuclei and prominent 1-4 nucleoli. Dividing decidual cells (B) and mitotic figure (arrow) are observed. GpII exhibited (c) thinner endometrial decidualization with (d) impaired differentiation of most of stromal cells into decidual cells. Few cells are demonstrating vesicular nuclei with prominent nucleoli (a and c x40, $\mathrm{b}$ and $\mathrm{d} \mathrm{x} 400$ ). Scale bar $200 \mu \mathrm{m}$ and $20 \mu \mathrm{m}$. 


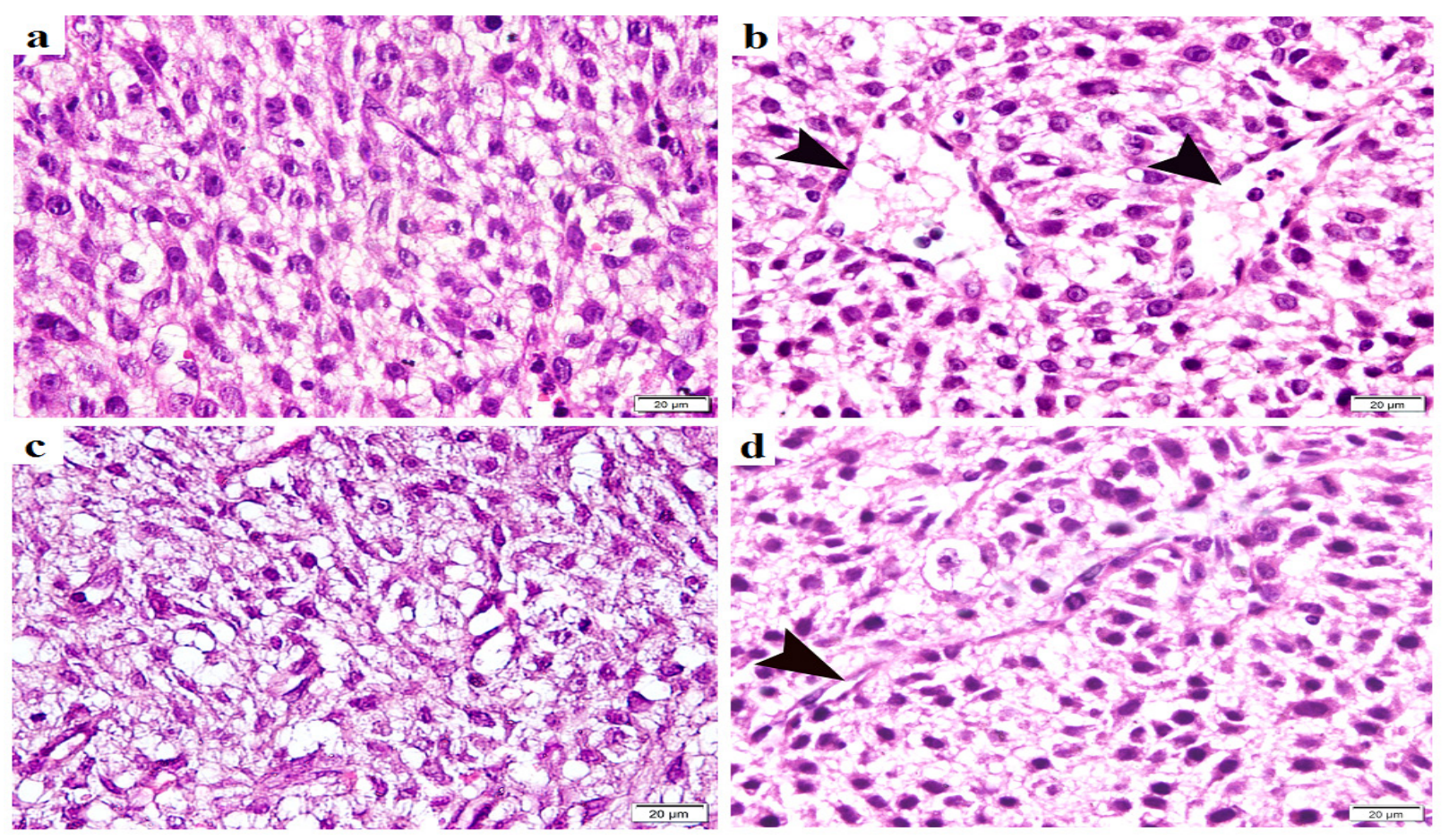

Fig. 4: Photomicrograph of H\&E stained sections showing the mesometrial and lateral decidul regions of the rat uteri at day 8 of pregnancy (x400). Gp I: (a) the mesometrial region illustrates small cells with irregular shape and a single nucleus. (b) the lateral decidua demonstrates formation of large venous sinusoids (arrow heads) harboring leukocytes. Gp II: (c) the mesometrial region displays small irregular shaped and spindle shape cells with single nucleus. (d) the lateral decidua exhibited small blood vessels with narrow lumen. Scale bar $20 \mu \mathrm{m}$.

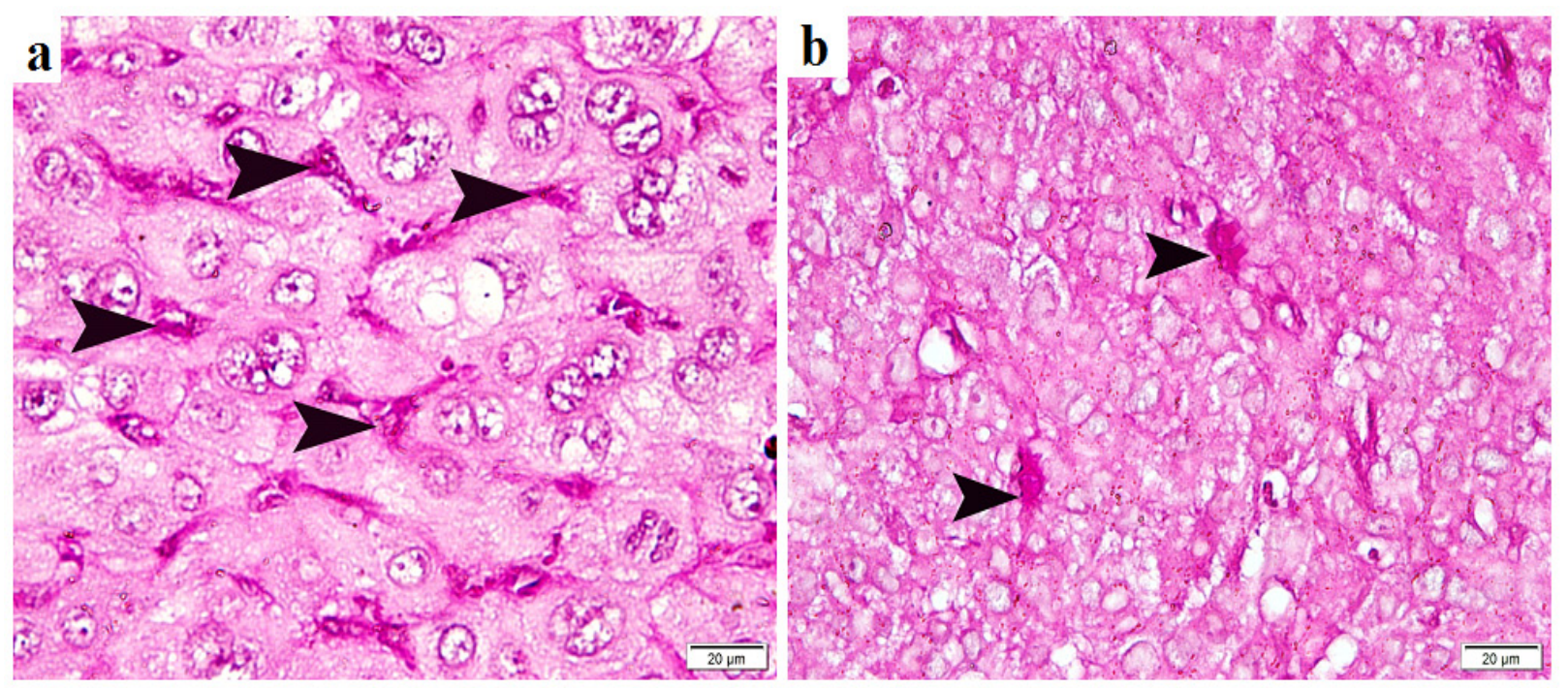

Fig. 5: Photomicrograph of PAS stained sections of the rat uteri at day 8 of pregnancy (x400). (a) Gp I displaying numerous uNK cells with PAS +ve reaction (arrowhead). (b) Gp II exhibiting few PAS positively stained uNK cells. Scale bar $20 \mu \mathrm{m}$. 

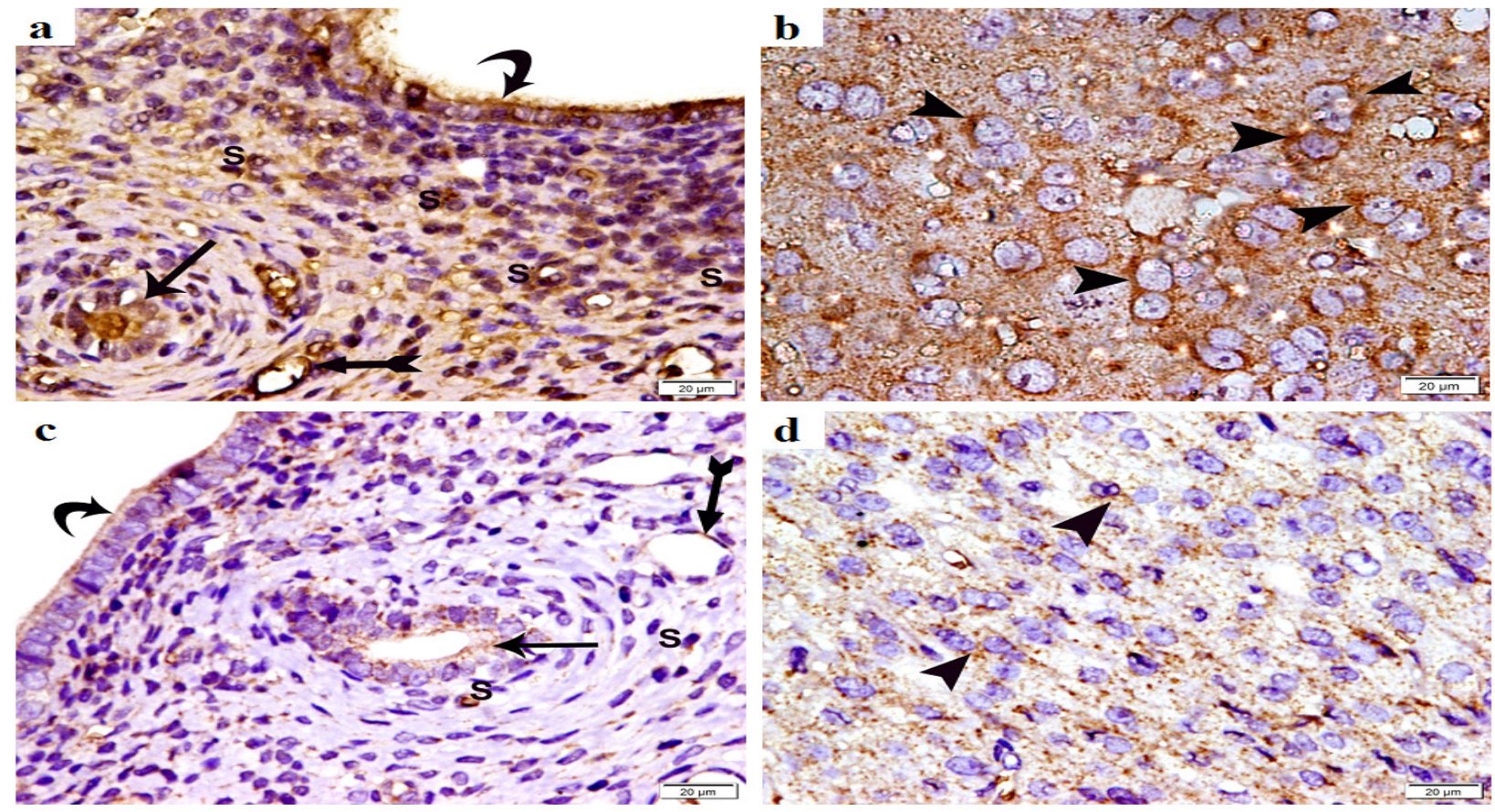

Fig. 6: Photomicrograph of osteopontin immunostained sections in rat uteri at day 8 of pregnancy (x400). Gp I demonstrating (a): strong +ve osteopontin (OSP) immunostaing in the cytoplasm of luminal (curved arrow) and glandular (arrow) epithelium, vascular endothelium (bifid arrow) and numerous stromal cells (S) in the mesometrial region. (b) Numerous decidual cells in the antimesometrial region strongly expressed +ve cytoplasmic OSP immunostaining (arrowhead). Gp II exhibiting (c): weak cytoplasmic OSP immunostaining in the luminal (curved arrow) and glandular (arrow) epithelium, vascular endothelium (bifid arrow) and few stromal cells (S) in the mesometrial region. (d): Weak cytoplasmic OSP immunostaining is observed in few cells in the antimesometrial region (arrowhead). Scale bar $20 \mu \mathrm{m}$.
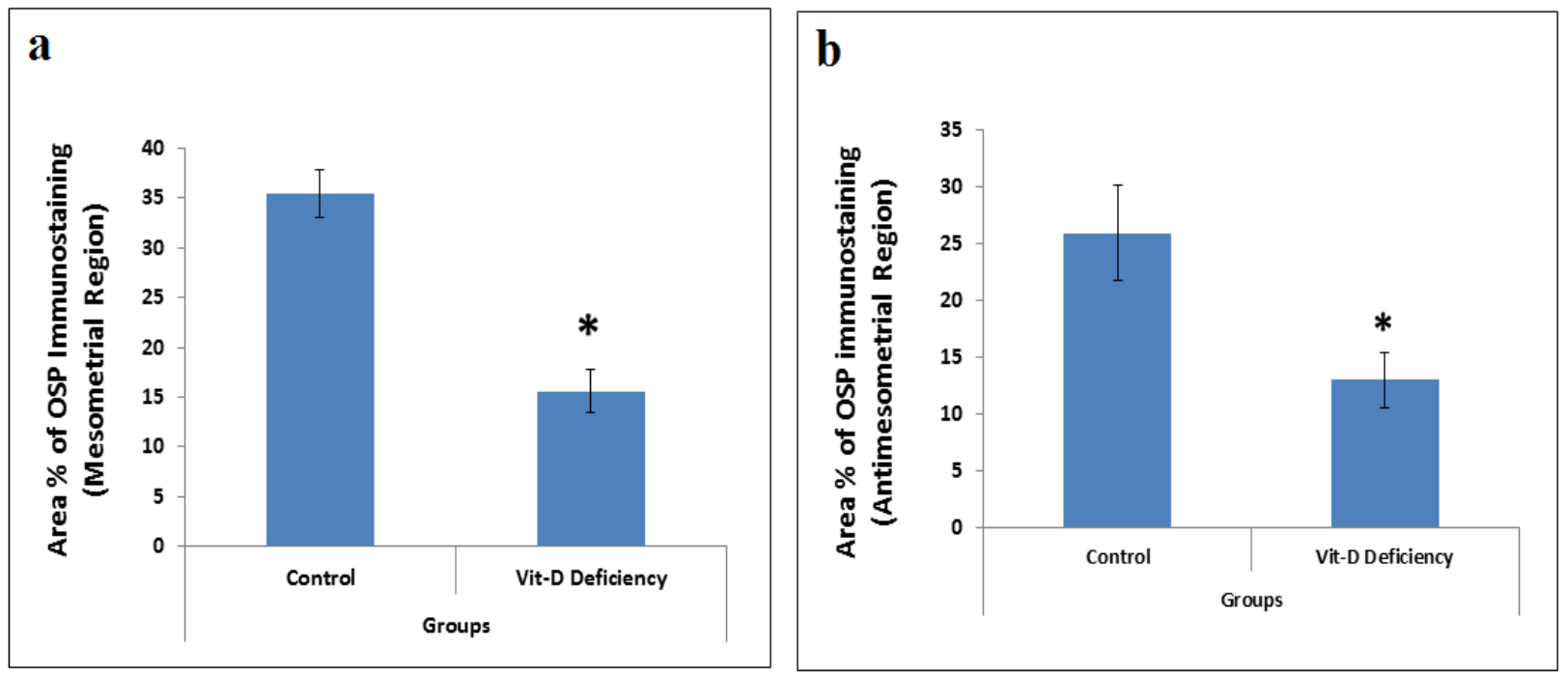

Fig. 7: Quantification of the mean area $\%$ of OSP $+v e$ immunostaining in the pregnant uterus at day 8 of pregnancy at: (a) the mesometrial and (b) antimesometrial regions. * Significant decrease as compared to control group. 

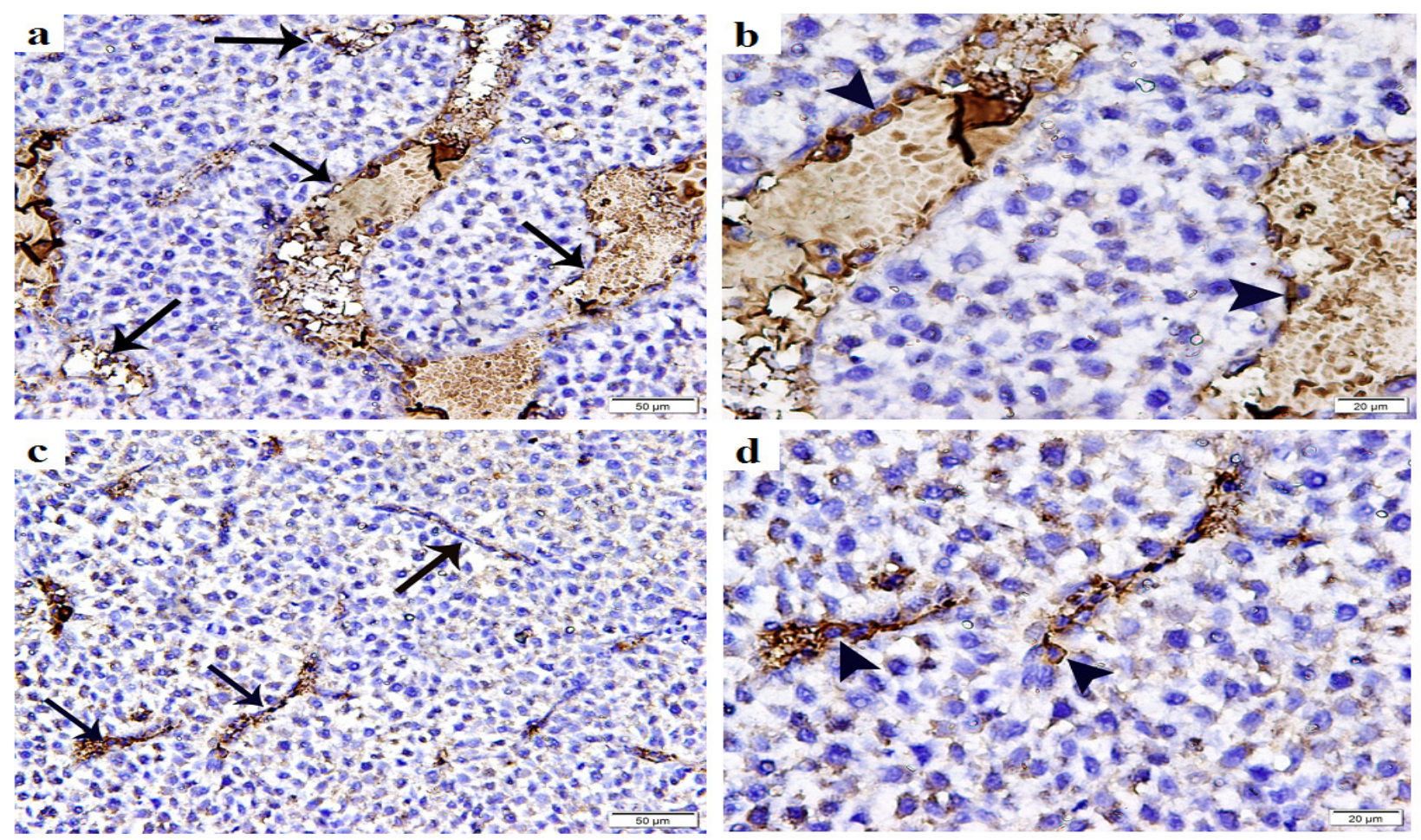

Fig. 8: Photomicrograph of cluster differentiation 34 (CD34) immunostained sections showing the lateral decidua of the rat uteri at day 8 of pregnancy. Gp I demonstrating: (a) numerous elongated well developed venous sinusoids (arrows) that appear in close contact with the decidual cells with (b) +ve CD34 immunostaining of endothelial cells (arrowhead). Gp II exhibiting: (c) poorly developed vascular sinusoids (arrows) displaying (d) +ve CD34 immunostaining of endothelial cells (arrowhead). (a and c x200, b and d x400). Scale bar $50 \mu \mathrm{m}$ and $20 \mu \mathrm{m}$.

\section{DISCUSSION}

The present work indicated that vitamin-D deficiency provides direct evidence of impaired pregnancy and decreased receptivity of the endometrium. This study succeeded in modeling vitamin-D deficiency in pregnant rats within 6 weeks before mating and throughout the 7 days of gestation which was verified by low serum blood level of Vit-D. Vitamin-D deficiency is defined by the Endocrine Society Clinical Practice Guideline as $25(\mathrm{OH}) \mathrm{D}$ less than $20 \mathrm{ng} / \mathrm{ml}(50 \mathrm{nmol} / \mathrm{L})$, and vitamin-D insufficiency as $25(\mathrm{OH}) \mathrm{D}$ range between 21-29 $\mathrm{ng} / \mathrm{ml}$ $(52.5-72.5 \mathrm{nmol} / \mathrm{L})^{17]}$. Noteworthy, vit-D deficiency was substantially associated with decrease in achieving pregnancy following IVF trails ${ }^{[18]}$. Besides, vit-D deficiency is strongly documented as a key regulator in women fertility problems ${ }^{[19]}$.

Histological analysis of the decidua in early pregnant control rats revealed striking full differentiation of stromal cells into numerous decidualized cells in the antimesometrial region. In addition, dividing cells and mitotic figures were observed. In rodents, decidualization is anatomically polarized process. Once blastocyst invasion, differentiation of the stromal cells of antimesometrial region is settled initially. It begins in the stromal cells from the subepithelial zone, then spread to the surrounding stromal cells. On 8th day of gestation, the decidual cells expand the whole thickness of the antimesometrial region ${ }^{[4]}$.

Vit-D deficient rats showed remarkably impaired stromal cells differentiation and proliferation with subsequent significant decrease in the mean endometrial thickness at the antimesometrial region, which could affect the pregnancy outcome and even the embryo growth. Vitamin-D joins its nuclear receptor that forms a complex which controls transcriptions of more than 200 genes implicated in metabolism, anabolism and mineral homeostasis and cell cycle control ${ }^{[20]}$. Moreover, vitamin-D exerts pro-differentiation activity in a variety of cell types achieved by enhancing the expression of growth factors and cytokines. In female reproductive system, it stimulates the production of progesterone which mediates the uterine function decidualization ${ }^{[21]}$.

The present work illustrated numerous uterine natural killer (uNK) cells with strong PAS +ve reaction in control rats. The uNK cells are the most prominant immune cells in the decidua during the first trimester of pregnancy, accounting $>70 \%$ of all leukocytes in the decidua ${ }^{[22]}$. In rodents, 2 types of uNK cells are identified by PAS and Dolichos Biflorus Agglutinin (DBA) reaction. PAS+DBAcells are involved in spiral arterial remodeling, while PAS+DBA+ cells produce angiogenic factors ${ }^{[23]}$. In 
contrast to peripheral blood, uNK cells are not cytotoxic but contain granules that are specialized for cytokines production. Besides, they differ phenotypically by being CD56bright (high density of expression), CD16- (identical to low cytotoxicity) and CD9+[3]. They contribute to the innate immunity as the first line of defense and induce tolerance of blastocyst during implantation. In addition, it secretes particular cytokines that are important during angiogenesis and spiral artery remodeling in placental bed ${ }^{[5]}$.

Meanwhile, Vit-D deficient rats exhibited significant decrease in the recruitment of PAS positively stained uNK cells into the early decidua. The abnormal regulation of NK cells in uterus and/or in blood can cause implantation failure or embryo loss during pregnancy. It was demonstrated that the decrease in uNK cells numbers leads to reproductive failure ${ }^{[24]}$. Immunomodulatory effects of Vit-D have been reported on both innate and adaptive immunity. Recently, A recent experimental study has shown the effects of vitamin-D on uNK cells functions improving their activity, cytokine secretion and receptor expression ${ }^{[25]}$.

Osteopontin is an adhesion molecule with roles in implantation and decidualization. In control rats, osteopontin immunostaining showed strong +ve cytoplasmic localization in the luminal and glandular epithelium, vascular endothelium and numerous stromal cells in the mesometrial region. Besides, numerous decidual cells have +ve strong cytoplasmic reaction in the antimesometrial region. In Rodents, OSP expression is upregulated in the pregnant uterus on 4 th to 8 th day ${ }^{[16]}$.

Vit-D deficient rats demonstrated few weak cytoplasmic OSP immunostaining in mesometrial and antimesometrial regions of the decidua. The mean area \% of OSP immunostaining in Vit-D deficient rats was significantly decreased in both regions of decidua as compared to the same regions in control group. The OSP gene expression in both cycling and early pregnant endometrium is stimulated by vitamin-D. During early pregnancy, OSP exerts its influence as a component of the endometrial gland secretion and as a product expressed by the uterine stroma [8], whereas it facilitates the decidual angiogenesis and vascular remodeling during the implantation window ${ }^{[26]}$. In addition, it contributes in the transformation of stromal cells into decidual cells, which correlates with the degree of blastocyst-hatching and adhesion. Thus, down-regulation of OSP has been accused in spontaneous abortion during early pregnancy ${ }^{[27]}$.

Immunostaining of CD34 showed numerous elongated dilated vascular sinusoids in the lateral decidua of control rats. Meanwhile, obvious impaired formation of decidual angiogenesis was observed in the lateral decidua of vit-D deficient rats. Recent evidence for the effect of vitamin-D on angiogenesis has been confirmed by studies working on endothelial colony forming cells. Thus, vitamin-D promotes the formation of capillary-like structures ${ }^{[28]}$. Maternal vitamin-D deficiency in mice exhibited decreased in the vascular diameter in the labyrinth zone, which is the highly vascular zone of the rodent placenta responsible for nutrient and waste exchange ${ }^{[29]}$. In addition, vit-D deficiency was accused in reduction of angiogenic factors expression, like vascular endothelial growth factor (VEGF), which is normally highly up-regulated during early decidualization for induction of angiogenesis. Reduction of VEGF was observed in maternal vit-D deficient mice with adverse consequences for the progression of pregnancy, placentation and the health of offspring ${ }^{[30]}$.

\section{CONCLUSION}

Vitamin-D deficiency substantially impairs the decidualization of the endometrium during early pregnancy in rat model by affecting the differentiation of the stromal cells into decidual cells. In addition, it influenced the OSP expression, the immunity tolerance and uNK cells recruitment and weakened the decidual angiogenesis.

\section{CONFLICT OF INTEREST}

There are no conflicts of interest.

\section{REFERENCES}

1. Mori M, Bogdan A, Balassa T, Csabai $\mathrm{T}$ and Szekeres-Bartho J: The decidua-the maternal bed embracing the embryo-maintains the pregnancy. Semin Immunopathol. (2016) 38(6): 635-649.

2. Faas MM and de Vos P: Uterine NK cells and macrophages in pregnancy. Placenta. (2017) 56: 44-52.

3. Soares MJ, Chakraborty D, Karim Rumi MA, Konno $\mathrm{T}$ and Renaud SJ: Rat placentation: an experimental model for investigating the hemochorial maternal-fetal interface. Placenta. (2012) 33(4): 233-243.

4. Fonseca BM, Correia-da-Silva $\mathrm{G}$ and Teixeira NA: The rat as an animal model for fetoplacental development: a reappraisal of the post-implantation period. Reprod Biol. (2012) 12(2): 97-118.

5. Norashikin MTS, Ghosh S, Chatterjee R, Rajikin $\mathrm{MH}$ and Chatterjee A: Nicotine and endometrial decidual growth in pseudopregnant rats. Reprod Med Biol. (2014) 13: 135-141.

6. Li Y, Gao R, Liu X, Chen X, Liao X, Geng Y, Ding $\mathrm{Y}$, Wang $\mathrm{Y}$ and He J: Folate Deficiency 
Could Restrain Decidual Angiogenesis in Pregnant Mice. Nutrients. (2015) 7(8): 6425-6445.

7. Wang X, Tan D, Ma J, Liang H, Zhang Q, Tan Y, Wang $\mathrm{J}$ and Luo W: Positive Regulation of Decidualization by 1-Type Amino Acid Transporter 1 (lat1) in Pregnant Mice. Nutrient. (2016) 8(11).

8. Viganò $\mathrm{P}$, Lattuada $\mathrm{D}$, Mangioni $\mathrm{S}$, Ermellino L, Vignali M, Caporizzo E, Panina-Bordignon P, Besozzi $M$ and Di Blasio AM: Cycling and early pregnant endometrium as a site of regulated expression of the vitamin D system. J Mol Endocrinol. (2006) 36(3): 415-4124.

9. Thangamani S, Kim M, Son Y, Huang X, Kim $\mathrm{H}$, Lee J H, Cho J, Ulrich B, Broxmeyer HE and Kim $\mathrm{CH}$. Cutting edge: progesterone directly upregulates vitamin $\mathrm{d}$ receptor gene expression for efficient regulation of $\mathrm{T}$ cells by calcitriol. J Immunol. (2015) 194: 883-886.

10. Kim CH: A Functional Relay from Progesterone to Vitamin D in the Immune System. DNA Cell Biol. (2015) 34(6): 379-82.

11. Tamblyn JA, Hewison M, Wagner CL, Bulmer $\mathrm{JN}$ and Kilby MD: Immunological role of vitamin $\mathrm{D}$ at the maternal-fetal interface. J Endocrinol. (2015) 224(3): R107-121.

12. Stavenuiter AW, Arcidiacono MV, Ferrantelli E, Keuning ED, Vila Cuenca M, ter Wee PM, Beelen RH, Vervloet MG and Dusso AS: A novel rat model of vitamin $\mathrm{D}$ deficiency: safe and rapid induction of vitamin D and calcitriol deficiency without hyperparathyroidism. Biomed Res Int. (2015) 2015: 604275 .

13. Hamid HY and Zakaria MZA: Reproductive characteristics of the female laboratory rat. Academic Journals. (2013) 12(19): 2510-2514.

14. Gois PH, Canale D, Luchi WM, Volpini RA, Veras MM, Costa Nde S, Shimizu MH and Seguro AC: Tenofovir during pregnancy in rats: a novel pathway for programmed hypertension in the offspring. J Antimicrob Chemother. (2015) 70(4): 1094-10105.

15. Kiernan J: Histological and histochemical methods: In: Theory and practice. (2001) 3rd ed. London, New York, New Delhi: Arnold publisher, 111-162.

16. Qi QR, Xie QZ, Liu XL and Zhou Y: Osteopontin is expressed in the mouse uterus during early pregnancy and promotes mouse blastocyst attachment and invasion in vitro. PLoS One. (2014) 9(8):e104955.

17. Holick MF, Binkley NC, Bischoff-Ferrari HA, Gordon CM, Hanley DA, Heaney RP, Murad $\mathrm{MH}$ and Weaver CM: Evaluation, treatment, and prevention of vitamin D deficiency: an Endocrine Society clinical practice guideline. J Clin Endocrinol Metab. (2011) 96(7): 1911-1930.

18. Polyzos NP, Anckaert E, Guzman L, Schiettecatte J, Van Landuyt L, Camus M, Smitz J and Tournaye $\mathrm{H}$ : Vitamin D deficiency and pregnancy rates in women undergoing single embryo, blastocyst stage, transfer (SET) for IVF/ ICSI. Human Reproduction. (2014) 29(9): 2032-2040.

19. Skowrońska P, Pastuszek E, Kuczyński W, Jaszczoł M, Kuć P, Jakiel G, WocławekPotocka I and Łukaszuk K: The role of vitamin $\mathrm{D}$ in reproductive dysfunction in women - a systematic review. Ann Agric Environ Med. (2016) 23(4): 671-676.

20. Haussler MR, Jurutka PW, Mizwicki $M$ and Norman AW: Vitamin D receptor (VDR)-mediated actions of $1 \alpha, 25(\mathrm{OH})_{2}$ vitamin $\mathrm{D}_{3}$ : genomic and non-genomic mechanisms. Best Pract Res Clin Endocrinol Metab. (2011) 25(4): 543-559.

21. Laganà AS, Vitale SG, Ban Frangež H, VrtačnikBokal E and D'Anna R: Vitamin D in human reproduction: the more, the better? An evidencebased critical appraisal. Eur Rev Med Pharmacol Sci. (2017) 21(18): 4243-4251.

22. Jabrane-Ferrat $\mathrm{N}$ and Siewiera $\mathrm{J}$ : The up side of decidual natural killer cells: new developments in immunology of pregnancy. Immunology 14. (2014) 141(4): 490-497.

23. Lima PD, TuMM, RahimMM, PengAR, Croy BA and Makrigiannis AP: Ly49 receptors activate angiogenic mouse DBA+ uterine natural killer cells. Cell Mol Immunol. (2014) 11:467-476.

24. Rodrigues MN, Favaron PO, Dombrowski JG, de Souza RM and Miglino MA: Role of natural killer (NK) cells during pregnancy: A review. Open Journal of Animal Sciences. (2013) 3 (2013) 138-144.

25. Lee GY, Cha KS, Park CY, Lee SE, Pae MK and Han SN: Differential Effect of Vitamin D Supplementation on Natural Killer Cell Activity 
in Normal and Obese Mice. The FASEB J. (2017) 31(1): supplement 964.9-964.9.

26. Gong X, Tong Q, Chen Z, Zhang Y, Xu C and Jin $\mathrm{Z}$ : Microvascular density and vascular endothelial growth factor and osteopontin expression during the implantation window in a controlled ovarian hyperstimulation rat model. Exp Ther Med. (2015) 9(3): 773-779.

27. Zhou H, Xu WM, Qi QR and Xie QZ: Osteopontin regulates trophoblast proliferation and invasion and associates with spontaneous abortion during early pregnancy. Int J Clin Exp Pathol. (2016) 9(5): 5230-5239.

28. Grundmann M, Haidar M, Hab S, Hubel CA and Versen-Hoynck Fv: Vitamin D promotes endothelial progenitor cell differentiation and upregulates VEGF. Pregnancy Hypertension: An International Journal of Women's Cardiovascular Health. (2012) 2:211.

29. Liu NQ, Ouyang Y, Bulut Y, Lagishetty V, Chan SY, Hollis BW, Wagner C, Equils O and Hewison M: Dietary Vitamin D Restriction in Pregnant Female Mice Is Associated With Maternal Hypertension and Altered Placental and Fetal Development. Endocrinology. (2013) 154: 2270-2280.

30. Tesic D, Hawes JE, Zosky GR and Wyrwoll CS: Vitamin D Deficiency in BALB/c Mouse Pregnancy Increases Placental Transfer of Glucocorticoids. Endocrinology. (2015) 156(10): 3673-3679. 


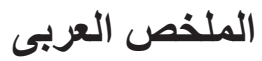

\title{
التقييم الهستولوجي لنقص فيتامين د على تكوين الفثاء السيَّاقطَي لبطانة الرحم في بداية الحمل في نموذج الفأر
}

\author{
سمـاء سمـير قمــر \\ قسم الهستولوجيا الطبية ، كلية الطب ، جامعة القاهرة ، القاهرة ، مصر
}

المقدمة : فيتامين د هو هرمون سيكوستيرويد متعدد المظاهر الذي يمارس التأثير الكلاسيكي في امتصاص الكالسيوم واستقلاب

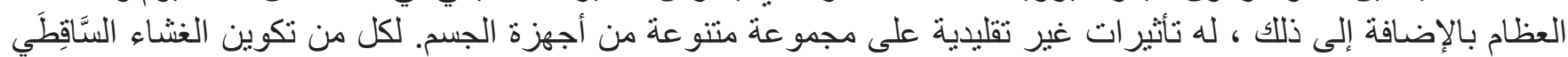

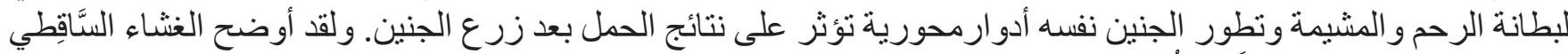

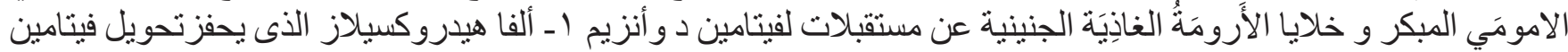

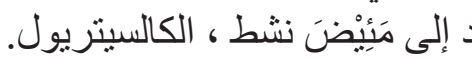

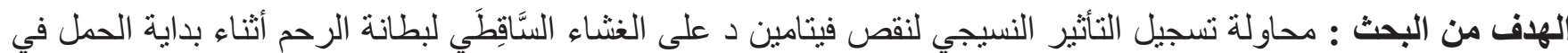
اليوم 8 بعد الجماع. مواد وطرق البحث: أدرج ثناثون من أنثى الفئر ان البيضاء في الدر اسة وقسمت إلى مجمو عتين: المجمو عة الضابطة (المجمو عة ،

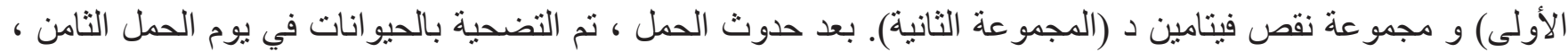

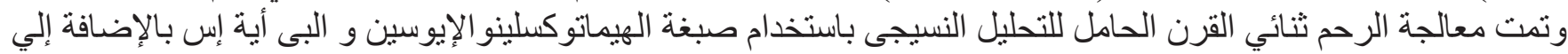

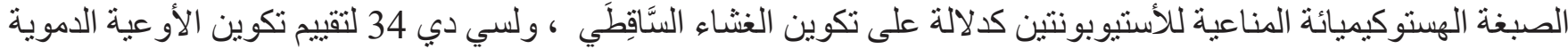

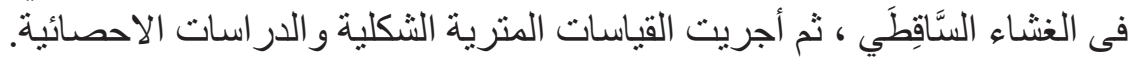

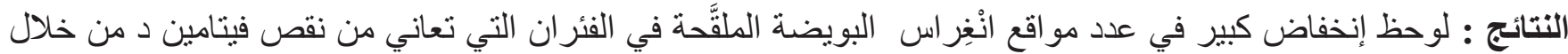

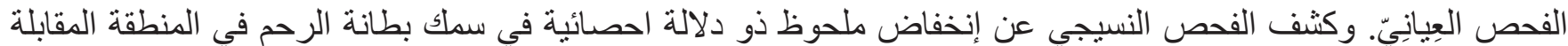

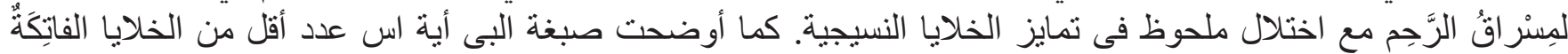

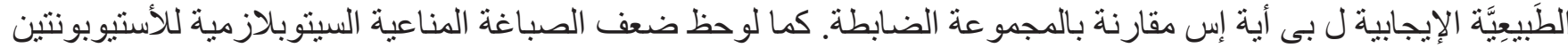

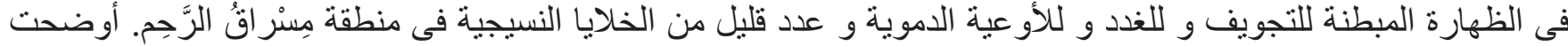

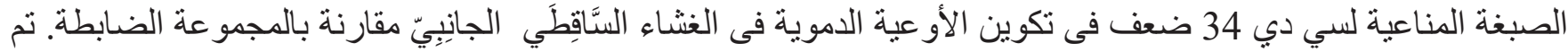
تأكيد هذه النتائج من خلال القياسات المتريةالثكلية و التحليل الإحصائي. الإستتناج : أشارت هذه النتائج إلى أن نقص فيتامين د يضعف تمايز الخلايا النسيجية للرحم ، ويؤثر على المناعة ويضعف

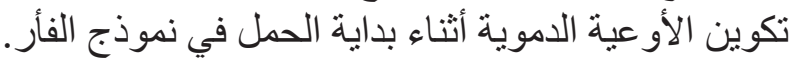

